\title{
The "Blue-collar" Motivation: Personal and Work Environment Predictors of Job Satisfaction among Construction Workers
}

\author{
Stefanovska-Petkovska, M., Bojazdiev, M., Handjiski, V. K., Trajkovska, V. \\ School of Business Economics and Management, University American College Skopje, Republic of Macedonia
}

Copyright $(2017$ by authors, all rights reserved. Authors agree that this article remains permanently open access under the terms of the Creative Commons Attribution License 4.0 International License

\begin{abstract}
The review of the academic literature reveals that job motivation is driven by the level of job satisfaction of employees. Hence, organizations that recognize the importance of satisfied employees are more likely to create flexible, loyal and creative workforce. This study is used to reexamine Frederick Herzberg's two-factor theory and its application in understanding what motivates manual workers in the construction industry. The data had been collected on 307 construction workers in Macedonia. The results indicated that personal characteristics did not influence job satisfaction among construction workers. However a significant influence of work environment characteristics on job satisfaction was found. Additionally, the results indicated that that the employees were not fully satisfied with the company's Opportunities for advancement. On the other hand, the motivation factors that lead to employees' satisfaction were the Responsibility factor, related to the available resources, tools, and physical environment, Good feelings about the organization, and Clarity of Mission. More relevant Hygiene factors to lead towards dissatisfaction were the Effectiveness of the supervisors, and Good relationship with co-workers.
\end{abstract}

Keywords Job Satisfaction, Motivation, Construction Industry, Employees, Herzberg

\section{Literature Review}

Motivation is defined as the individual forces, which account for the direction, level, and persistence of a person's effort at work (1). This direction of person's behavior includes the potential behaviors in which an employee could engage, while, the level of effort refers to how hard the employees work with the intention to provide superior service, and finally identifies that the level of persistence is determined when an employee is faced with certain obstacles
(2). Consequently, Gitman and Mc Daniel (3) discuss that motivation is the set of forces that prompts an individual to deliver efficiency and energy in certain direction. As a result, motivation is determined as a need (defined as the gap between what is and what is required) and want (defined as the gap between what is and what is desired) satisfying process. Therefore, unfulfilled needs and wants develop state of tension that motivates individuals to practice behavior, which will result in the need being met, or want being fulfilled. The concept of motivation, according to Wellington (4), is viewed as individual feeling a strong emotional connection to the organization, indicating willingness to recommend the organization to others, and committing time and effort to helping the organization succeed. Furthermore, Walker and Miller (5) state that the term motivation refers to what makes people tick: the needs, desires, fears and aspirations within individuals that make them behave as they do. Hence, highly motivated employees work hard and do exceptional work, while poorly motivated employees do what is necessary, even though they may be capable of performing better at work. On the other hand unmotivated employees perform marginally and generally take up a good value of the employer's time.

The review of the academic literature reveals that job motivation is driven by the level of job satisfaction of employees. A range of authors' state that this is the crucial part of motivation and it is determined as the person's general attitude toward his job $(6 ; 7 ; 8)$. Job satisfaction is defined as an inner fulfillment and satisfaction, acquired through performing a particular job (9). Moreover, Moerdyk et al. discuss that a person that enjoys a high level of job satisfaction will have a positive attitude towards that job, while a person that is dissatisfied, will have a negative attitude about that particular job, which in turn displays that job satisfaction is an emotional state resulting from evaluating personal job experiences.

Consequently, Armstrong (10) points out that the basic requirements for job satisfaction may include comparatively 
higher pay, an equitable payment system, opportunities for promotion, considerate and participative management, acceptable degree of social interaction at work, diverse tasks and a high degree of autonomy, such as control over work methods. Consequently, the degree of satisfaction achieved by individuals depends largely on their needs, their expectations, and the working environment and acquiring positive attitudes towards the particular job, can result in job satisfaction. Therefore, according to the academic findings, organizations that recognize the importance of satisfied employees are more likely to create flexible, loyal and creative workforce.

\section{Methodology}

The research is modeled around previous research done in the field (11). Based on the review of the academic literature, the following research questions were set: which factors have the highest potential to lead towards employees job satisfaction and dissatisfaction, what is the influence of personal and job characteristics on job satisfaction among construction workers in Macedonia, and whether, Herzberg's two factor theory is relevant in the context of the Macedonian construction industry? An important variable in this research is job satisfaction, and is built on several items from the questionnaire, such as: overall satisfaction with current job and the extent to which the current job meets the individuals' expectation. Personal characteristics of the participants include age, gender, and marital status, number of children, education and ethnic minority status. Job characteristics are: tenure and supervisory role.

\subsection{Research Approach and Instrument}

For the purpose of this research a quantitative approach was applied using a questionnaire as the main research instrument. The questionnaire represented an adapted version of a research instrument originally developed by Smerek and Peterson (11) and was applied through personal approach among employees in a company operating in the construction industry in Republic of Macedonia. A pilot testing was administered, through distributing copies of the questionnaire among 10 employees, in order to disclose potential defects in the instrument and assess if employees understood the questions and if they were able to provide adequate answers. The questionnaire was written in Macedonian language in order to avoid any misunderstanding, and was consisted of items covering the following topics: work itself, opportunities for advancement, responsibility; collaboration and teamwork; communication, effective supervision, alignment with mission and goals; and feelings about one's job.

More specifically, the instrument was comprised of a total of 40 questions, 10 of which were related to demographic information, such as, gender, age, ethnicity, education, marital status, number of children, department, length of service, etc. Twenty-five statements were used to examine the motivation factors and hygiene factors, measured on a four point Likert-type scale ranging from strongly disagree to strongly agree. From the Motivator factors, two items were used to assess the work itself, another two items, assessed the opportunities for advancement, while, three items were related to the employee's responsibility and physical environment. Furthermore, another two items were used to examine the employees' feelings about the organization, and the final item was related to and assessed the clarity of mission dimension. On the other hand, from the Hygiene factors, nine items were used to assess the supervisor and its effective management of employees, while, four items from this factors, were used to assess the relationship with co-workers. The remaining two items from the four- point Liker scale were statements related to workplace safety and job safety; The last five questions from the questionnaire were related to the overall job satisfaction and were measured on a five-point Likert type scale. The factor analyses confirmed the grouping of the variables (Table 1). The analyses indicated Cronbach Alpha values that are higher than 0.7 making them acceptable for further analyses. 
Table 1. Results of factor analyses

\begin{tabular}{|c|c|c|c|}
\hline & Rotated component matrix & $\begin{array}{l}\text { Factor1-Motiva } \\
\text { tional Factors }\end{array}$ & $\begin{array}{l}\text { Factor } 2 \text { - Hygiene } \\
\text { factors }\end{array}$ \\
\hline \multirow{2}{*}{ Work itself } & My job is interesting and I enjoy doing it & .771 & .113 \\
\hline & My job gives me a sense of accomplishment & .823 & .127 \\
\hline \multirow{2}{*}{$\begin{array}{l}\text { Opportunities } \\
\text { for } \\
\text { Advancement }\end{array}$} & $\begin{array}{l}\text { The company in which I work provides opportunities for advancement and } \\
\text { promotion }\end{array}$ & .751 & .315 \\
\hline & Information about job vacancies within the company are internally available & .784 & .148 \\
\hline \multirow{3}{*}{ Responsibility } & I have control over how I do my work & .859 & .152 \\
\hline & $\begin{array}{l}\text { The physical environment in which I work is suitable and allows me to do my } \\
\text { job }\end{array}$ & .854 & .029 \\
\hline & I have the necessary resources, tools and equipment to do my job & .901 & .011 \\
\hline \multirow{2}{*}{$\begin{array}{l}\text { Good feelings } \\
\text { about the } \\
\text { organization }\end{array}$} & I am proud to work for this company & .773 & 0.32 \\
\hline & I care about the future of the company in which I work & .776 & .167 \\
\hline $\begin{array}{c}\text { Clarity of } \\
\text { mission }\end{array}$ & $\begin{array}{l}\text { I understand how my work contributes for the achievement of the company's } \\
\text { goal }\end{array}$ & .721 & .165 \\
\hline \multirow{9}{*}{$\begin{array}{l}\text { Effective } \\
\text { Supervisor }\end{array}$} & The supervisor adequately informs its employees & .217 & .813 \\
\hline & My supervisor communicates well & .186 & .765 \\
\hline & Supervisors manage employees effectively & .182 & .713 \\
\hline & Supervisors make effective decisions & .049 & .753 \\
\hline & Supervisors care about their employees & .018 & .817 \\
\hline & My supervisor is approachable at any time and easy to talk with & .193 & .850 \\
\hline & My supervisor trusts me & .092 & .849 \\
\hline & My supervisor considers my ideas & .034 & 0.750 \\
\hline & My supervisor recognizes me for doing good work & .029 & .755 \\
\hline \multirow{4}{*}{$\begin{array}{c}\text { Good } \\
\text { relationship } \\
\text { with co-workers }\end{array}$} & I trust my co-workers & .050 & .903 \\
\hline & My co-workers respect me & .015 & .786 \\
\hline & I can count on my co-workers to help out when needed & .238 & .852 \\
\hline & My co-workers and I work as part of a team & .210 & .912 \\
\hline $\begin{array}{l}\text { Workplace } \\
\text { safety }\end{array}$ & Safety at the workplace is according to the established standards & .005 & .744 \\
\hline Job safety & My working position is stable and I do not fear that I might be fired & .095 & .886 \\
\hline
\end{tabular}

Extraction Method: Principal Component Analysis.

Rotation Method: Varimax with Kaiser Normalization.

a. Rotation converged in 2 iterations.

\subsection{Data Collection and Research Design}

The data had been collected in a period of nine working days and 350 questionnaires were distributed among the construction workers, from which a total number of 307 questionnaires were returned. The response rate was $87.75 \%$ characterized as a healthy response rate. Participation in the study was voluntary and those subjects not willing to participate, were obliged to return the empty questionnaire. The survey was administered after previous approval from the management. Each construction worker was given a questionnaire during their lunch break and was informed about the anonymity and confidentiality of the data. A special box was placed so that the workers may leave their completed questionnaire independently. No representatives or supervisors were present during the completion of the questionnaires in order to avoid the occurrence of social bias.

\subsection{Site Selection}

The company belongs to the private sector and provides services in accordance with all the legal norms in the construction business, associated with production, construction, trading and services industry, and therefore, it has grown into one of the most important construction companies within the borders of Republic of Macedonia

\subsection{Statistical Analyses}

The descriptive analysis was through using an excel spreadsheets while the statistical operations were made in SPSS 22. The personal characteristics of the respondents were analysed in order to investigate and interpret the research questions of the questionnaire. Furthermore, descriptive analysis of job satisfaction and perceived work environment, and an analysis of job satisfaction and personal 
characteristics, such as age and marital status was conducted. Additionally, $t$-tests were made for the purpose of identifying any possible significant differences among the categorical variables of gender and tenure with the items concerning the hygiene- motivation factors and job satisfaction. Moreover, an analysis of variance (ANOVA) was used to assess and compare the possible variances between and within different groups' marital status with perceived work environment and job satisfaction.

\subsection{Demographic Profile of the Research Population}

Table 2. Demographic profile of research participants

\begin{tabular}{|c|c|}
\hline Respondents' Characteristics & Percentages \\
\hline $\begin{array}{l}\text { Gender } \\
\text { Male } \\
\text { Female }\end{array}$ & $\begin{array}{l}70.9 \% \\
29.1 \%\end{array}$ \\
\hline $\begin{array}{c}\text { Age } \\
18-24 \\
25-34 \\
35-44 \\
45-54 \\
55-64 \\
\text { Above65 }\end{array}$ & $\begin{array}{c}5.8 \% \\
17.5 \% \\
24.3 \% \\
34 \% \\
17.5 \% \\
1 \%\end{array}$ \\
\hline $\begin{array}{l}\text { Ethnicity } \\
\text { Macedonian } \\
\text { Albanian } \\
\text { Serbian } \\
\text { Turk } \\
\text { Other }\end{array}$ & $\begin{array}{c}93.2 \% \\
1.9 \% \\
\\
2.9 \% \\
1 \% \\
1 \%\end{array}$ \\
\hline $\begin{array}{c}\text { Education } \\
\text { Middle school degree } \\
\text { High school degree } \\
\text { Bachelor's degree }\end{array}$ & $\begin{array}{c}3.9 \% \\
68.9 \% \\
27.2 \%\end{array}$ \\
\hline $\begin{array}{c}\text { Marital status } \\
\text { In a relationship } \\
\text { Married } \\
\text { Divorced } \\
\text { Widowed } \\
\text { Single } \\
\text { *1.9\%(N=2) have not given an } \\
\text { answer to this question. }\end{array}$ & $\begin{array}{c}11.7 \% \\
73.8 \% \\
2.9 \% \\
/ \\
9.7 \%\end{array}$ \\
\hline $\begin{array}{c}\text { Years of Experience } \\
\text { Lessthan6months } \\
\text { 6months-1year } \\
1-5 \text { years } \\
5-15 \text { years } \\
\text { Above15years }\end{array}$ & $\begin{array}{c}5.8 \% \\
4.9 \% \\
26.2 \% \\
52.4 \% \\
10.7 \% \\
\end{array}$ \\
\hline
\end{tabular}

From a total of 307 respondents, $70.9 \%(\mathrm{~N}=217)$ were male, while $29.1 \%(\mathrm{~N}=89)$, were female (Table 2). The majority of the respondents in this questionnaire were Macedonian $93.2 \%(\mathrm{~N}=286)$, and most of the respondents $68.9 \%(\mathrm{~N}=211)$, had a high school degree. On the other hand, demographic information regarding the marital status of the participants has demonstrated that the majority of the respondents were married $73.8 \%(\mathrm{~N}=226)$, and most of them had children $71.9 \%(\mathrm{~N}=220)$. Moreover, $70.9 \%$ $(\mathrm{N}=217)$ of the respondents stated that other members of their family that lived with them, were also working (Table $1)$.
According to the position type, the majority of the respondents in this survey or, $65 \%(\mathrm{~N}=205)$ were working on positions such as: production, maintenance, commerce, lock smiting, glassware, tailoring, steel constructions, transport, aluminium plant, etc. On the other hand, $11,7 \%$ $(\mathrm{N}=35)$ were administration workers (on positions such as, accounting, legal sector, design etc.), whereas the remaining $23.3 \%(\mathrm{~N}=71)$ have not given any reply regarding their working position. In addition, another demographic aspect of the questionnaire was related to the time of employment within the company (Table 1), therefore, in terms of number of years of work experience most of the respondents had between 5 to 15 years of work experience within the company, $52.4 \%(\mathrm{~N}=160)$.

\section{Job Satisfaction and Perceived Work Environment}

The statement "I have control over how I do my work" is concerning the responsibility dimension, and the mean of the employees' responses was 3.72, while $\mathrm{SD}=0.493$. Moreover, on the statement whether "The physical environment in which I work is suitable and allows me to do my job" $\mathrm{M}=3.70$, while, $\mathrm{SD}=0.591$. In addition, the mean and standard deviation gained for the statement "I have the necessary resources, tools and equipment to do my job" were $\mathrm{M}=3.70$ and $\mathrm{SD}=0.608$. Furthermore, two items were concerned with the employees' feelings about the organization, therefore, for the statement "I am proud to work for this company" from a total of 103 respondents, $\mathrm{M}=3.64$ and the $\mathrm{SD}=0.608$. Moreover, on the statement "I care about the future of the company in which I work", $\mathrm{M}=3.87$, while the $\mathrm{SD}=0.362$. Additionally, the response rate gained on the statement concerning the clarity of mission," I understand how my work contributes for the achievement of the company's goal" was $\mathrm{M}=3.76$ and $\mathrm{SD}=0.494$.

The following statements are related to the Hygiene Factors, and are concerning the assessment of the effectiveness of the supervisor (nine items) and the relationship with co- workers (four items). Therefore, on the statement "The supervisor adequately informs its employees", the gained mean value of the responses was $\mathrm{M}=3.28$, and the standard deviation was, $\mathrm{SD}=0.821$. Furthermore, on the statement "My supervisor communicates well", the $\mathrm{M}=3.45$, while the $\mathrm{SD}=0.776$. The response rate on whether "Supervisors manage employees effectively" was $\mathrm{M}=3.33$, and the $\mathrm{SD}=0.746$. In addition, another statement, concerning the effectiveness of supervisors, was whether "Supervisors make effective decisions", for which the mean value of responses was $\mathrm{M}=3.27$, while the $\mathrm{SD}=0.769$. On the statement, "Supervisors care about their employees", the mean was 3.31 and the SD was 0.841 . Moreover, the mean value gained from the statement "My supervisor is approachable at any 
time and easy to talk with" was 3.52 and the $\mathrm{SD}=0.654$. Furthermore, on the statement "My supervisor trusts me", $\mathrm{M}=3.42$, and the $\mathrm{SD}=0.748$, while, on the statement "My supervisor considers my ideas" the mean value of the total 103 responses was 3.25 , and the $\mathrm{SD}=0.750$. Additionally, one item from the Hygienic factors-effective supervisor dimension, "My supervisor recognizes me for doing good work", received the lowest mean of 2.95 and $\mathrm{SD}=0.954$.On the other hand, the answer to the statement, whether "I trust my co-workers" related to the relationship with co-workers, resulted in the mean value being 3.43 and the SD being 0.651 . Additionally, another statement concerning the relationship with co- workers was, "My co-workers respect me", for which the mean value of responses was 3.46 and the
$\mathrm{SD}=0.638$. For the question "I can count on my co-workers to help out when needed", $\mathrm{M}=3.53$, and the $\mathrm{SD}=0.698$. Finally, the last statement of the good relationship with co-workers dimension was, "My co-workers and I work as part of a team", for which the acquired mean value from the total 103 responses, was 3.55 , while the $\mathrm{SD}=0.776$. From the remaining two statement, one statement was assessing whether the safety at the workplace was according to the established standards, for which, $\mathrm{M}=3.60$, while the $\mathrm{SD}=0.600$. In addition, the mean gained from the data collected on the last statement $t$, "My working position is stable and I do not fear that I might be fired", was $\mathrm{M}=3.33$, while the $\mathrm{SD}=0.845$.

Table 3. Descriptive analysis of job satisfaction and perceived work environment (Hygiene and Motivational Factors)

\begin{tabular}{|c|c|c|c|c|}
\hline \multicolumn{2}{|r|}{ Factors } & Statements & $\begin{array}{c}\text { Mean } \\
(N=103)\end{array}$ & $\begin{array}{c}\text { Std. } \\
\text { Deviation }\end{array}$ \\
\hline \multirow{11}{*}{$\begin{array}{l}\text { MOTIVATI } \\
\text { ON }\end{array}$} & \multirow{3}{*}{ Work itself } & & 236 & \\
\hline & & My job is interesting and 1 enjoy doing it & 3,36 & 0.698 \\
\hline & & My job gives me a sense of accomplishment & 3,26 & 0.792 \\
\hline & \multirow{2}{*}{$\begin{array}{l}\text { Opportunities for } \\
\text { Advancement }\end{array}$} & $\begin{array}{l}\text { The company in which I work provides opportunities for } \\
\text { advancement and promotion }\end{array}$ & 3,1 & 0.955 \\
\hline & & $\begin{array}{l}\text { Information about job vacancies within the company are internally } \\
\text { available }\end{array}$ & 3,17 & 0.909 \\
\hline & \multirow{3}{*}{ Responsibility } & I have control over how I do my work & 3,72 & 0.493 \\
\hline & & $\begin{array}{l}\text { The physical environment in which I work is suitable and allows } \\
\text { me to do my job }\end{array}$ & 3,7 & 0.591 \\
\hline & & I have the necessary resources, tools and equipment to do my job & 3,7 & 0.608 \\
\hline & \multirow{2}{*}{$\begin{array}{l}\text { Good feelings about the } \\
\text { organization }\end{array}$} & I am proud to work for this company & 3,64 & 0.608 \\
\hline & & I care about the future of the company in which I work & 3,87 & 0.362 \\
\hline & Clarity of mission & $\begin{array}{l}\text { I understand how my work contributes for the achievement of the } \\
\text { company's goal }\end{array}$ & 3,76 & 0.494 \\
\hline \multirow{15}{*}{ HYGIENE } & \multirow{9}{*}{ Effective Supervisor } & The supervisor adequately informs its employees & 3,28 & 0.821 \\
\hline & & My supervisor communicates well & 3,45 & 0.776 \\
\hline & & Supervisors manage employees effectively & 3,33 & 0.746 \\
\hline & & Supervisors make effective decisions & 3,27 & 0.769 \\
\hline & & Supervisors care about their employees & 3,31 & 0.841 \\
\hline & & My supervisor is approachable at any time and easy to talk with & 3,52 & 0.654 \\
\hline & & My supervisor trusts me & 3,42 & 0.748 \\
\hline & & My supervisor considers my ideas & 3,25 & 0.750 \\
\hline & & My supervisor recognizes me for doing good work & 2,95 & 0.954 \\
\hline & \multirow{4}{*}{$\begin{array}{l}\text { Good relationship with } \\
\text { co-workers }\end{array}$} & I trust my co-workers & 3,43 & 0.651 \\
\hline & & My co-workers respect me & 3,46 & 0.638 \\
\hline & & I can count on my co-workers to help out when needed & 3,53 & 0.698 \\
\hline & & My co-workers and I work as part of a team & 3,55 & 0.776 \\
\hline & Workplace safety & Safety at the workplace is according to the established standards & 3,6 & 0,6 \\
\hline & Job safety & $\begin{array}{l}\text { My working position is stable and I do not fear that I might be } \\
\text { fired }\end{array}$ & 3,33 & 0.845 \\
\hline
\end{tabular}


Table 4. Regression analysis results

\begin{tabular}{|c|c|c|c|c|c|}
\hline \multirow[b]{2}{*}{ Model } & \multicolumn{2}{|c|}{ Unstandardized Coefficients } & \multirow{2}{*}{$\begin{array}{c}\text { Standardized Coefficients } \\
\text { Beta }\end{array}$} & \multirow[t]{2}{*}{$\mathrm{T}$} & \multirow[t]{2}{*}{ Sig. } \\
\hline & B & Std. Error & & & \\
\hline (Constant) & 1.167 & .228 & & 5.429 & .000 \\
\hline Clarity of mission & .059 & .041 & .068 & 1.550 & .158 \\
\hline Opportunities for advancement & .058 & .033 & .212 & 1.654 & .000 \\
\hline Responsibility & .145 & .035 & .219 & 4.151 & .000 \\
\hline Good feelings about org. & .180 & .045 & .056 & 4.856 & .000 \\
\hline Work itself & .180 & .038 & .210 & 4.979 & .000 \\
\hline Effective supervisor & .110 & .047 & .154 & 2.559 & .023 \\
\hline $\begin{array}{c}\text { Good relationship with } \\
\text { co-workers }\end{array}$ & .165 & .091 & .321 & 4.411 & .000 \\
\hline Workplace safety & .187 & .039 & .254 & 1.232 & .018 \\
\hline Job safety & .056 & .042 & .308 & 4.217 & .000 \\
\hline
\end{tabular}

a. Dependent Variable: Job satisfaction

Testing the relationship between work environment factors (Hygiene and Motivational) and Job satisfaction was done by regression analyses. The analysis showed that $51 \%$ of the variance in the dependent variable job satisfaction was explained by the independent variables and the overall model can statistically significant predict the outcome variable $(\mathrm{F}=38,671 ; \mathrm{p}<0.01)$. The results in Table 4 show that the Hygiene factors: satisfaction with responsibility $(\beta=0.219, p<0.01)$, opportunities for advancement $(\beta=0.212, p<0.01)$, work itself $(\beta=0.210, p<0.01)$ and good feelings about organization $(\beta=0.056, p<0.00)$ significantly predict job satisfaction. Additionally the following Motivation factors significantly predict job satisfaction: effective supervision $(\beta=0.154, p<0.05)$, good relationship with co-workers $(\beta=0.321, p<0.01)$, work safety $(\beta=0.254, p<0.05)$ and job safety $(\beta=0.308, \mathrm{p}<0.01)$.

\section{Descriptive Analysis of Job Satisfaction and Personal Characteristics}

The following paragraphs will provide information of an analysis based on job satisfaction and employees personal characteristics: age, marital status and ethnicity.

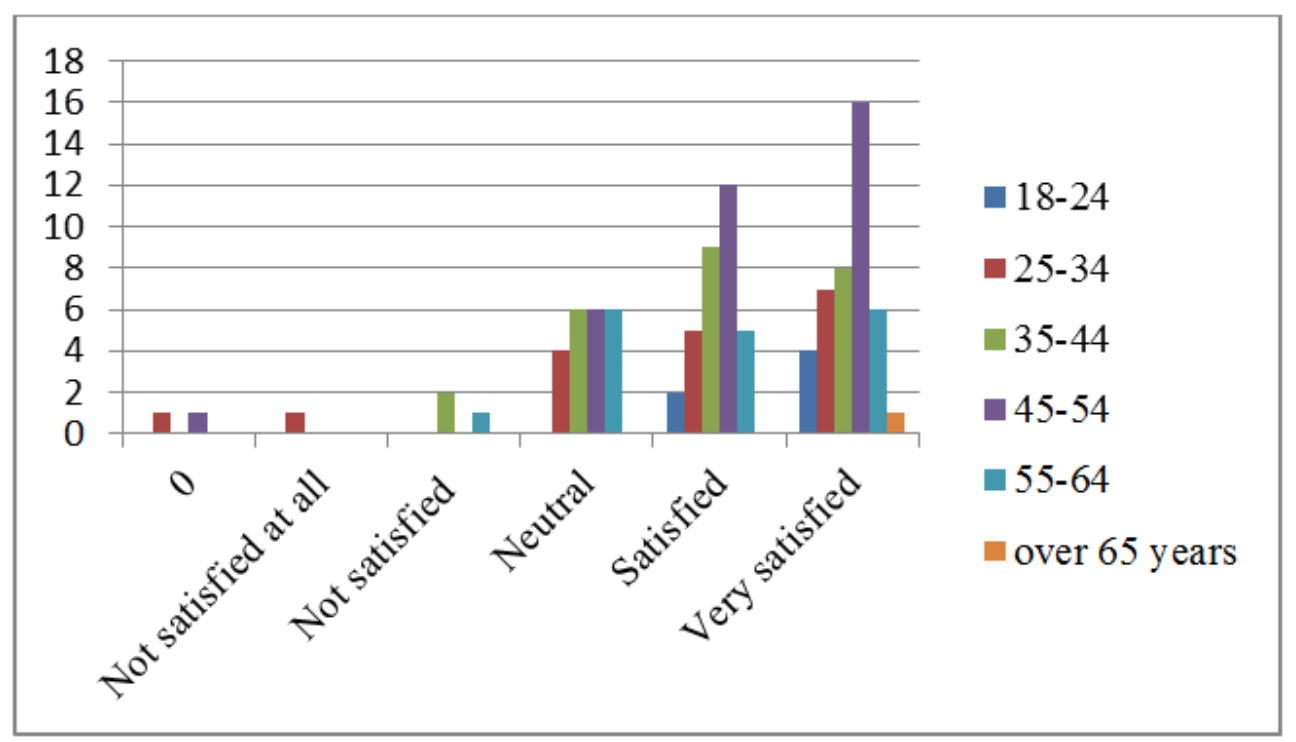

Chart 1. Overall, how satisfied are you with your job (from1-5)? Personal characteristic: Age

Chart 1 gives an illustration and compares the data collected for the first personal characteristic assessed, which was the age of the respondents. As suggested by the research results, reported job satisfaction among construction workers tends to be higher among the older groups of employees compared to the younger groups. 


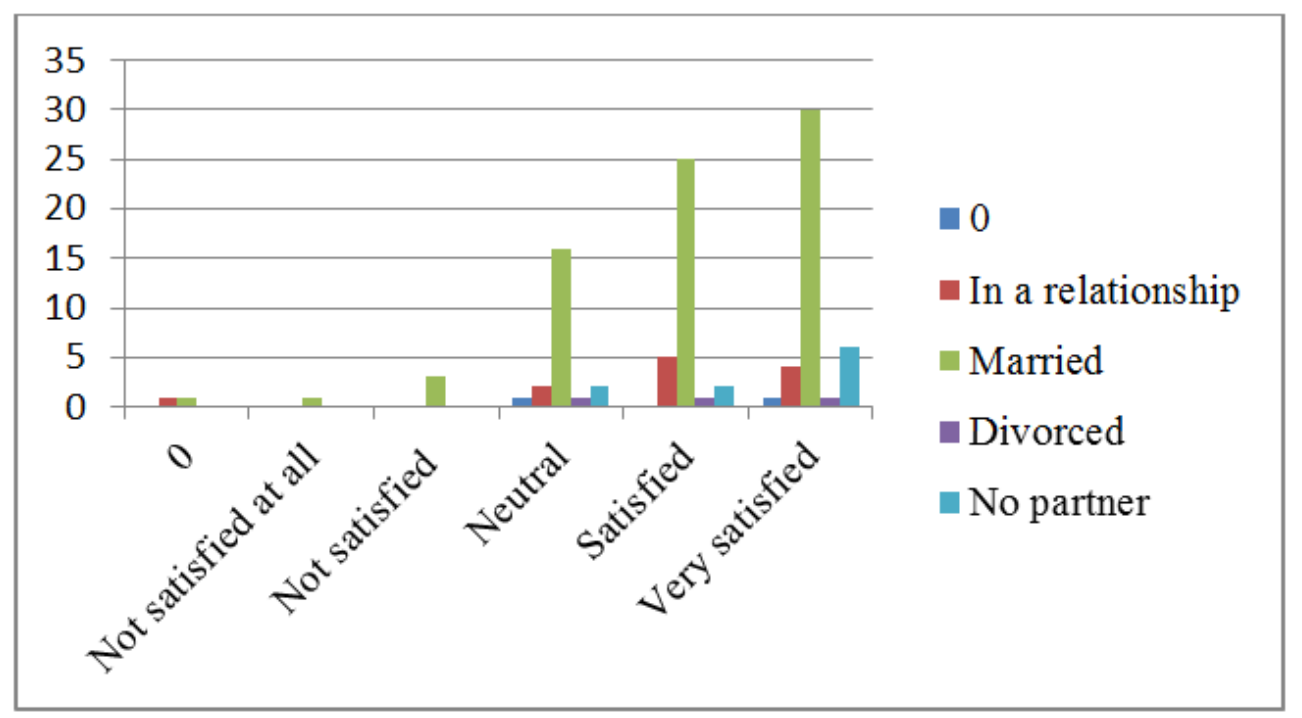

Chart 2. Overall, how satisfied are you with your job (from1-5)? Personal characteristic: Maritalstatus

Chart 2 gives an illustration and compares the data collected for the second personal characteristic assessed, which was the marital status of the respondents. For this purpose, the respondents were asked to disclose information and were evaluated based on whether they were in a relationship, married, divorced or single, on the question "How satisfied they were with their job?" The results indicated that construction workers that were married, followed by those that were in a relationship, tended to have a higher level of reported job satisfaction compared to the group that was not in a relationship or widow/er.

T-tests were used to identify the significant differences among the categorical variables of gender and minority status with work environment factors and job satisfaction.

An independent samples t-test was conducted to compare the level of job satisfaction of different genders (male and female). The results showed that there was not a significant difference in the scores for male $(\mathrm{M}=4.05, \mathrm{SD}=1.079)$ and female $(\mathrm{M}=3.97, \mathrm{SD}=1.066)$ on the overall level of job satisfaction $\mathrm{t}(101)=0.378, \mathrm{p}(0.706)$. But, there was a statistically significant difference between male $(\mathrm{M}=3.63$, $\mathrm{SD}=0.656)$ and female $(\mathrm{M}=3.87, \mathrm{SD}=0.346)$ employees on the item "The physical environment in which I work is suitable and allows me to do my job", related to the Responsibility dimension from the motivation factors $\mathrm{t}$ (101) $=-1.867, \mathrm{p}=0.065$. In addition, there was also a significant difference between male $(\mathrm{M}=3.56, \mathrm{SD}=0.645)$ and female $(\mathrm{M}=3.83, \mathrm{SD}=0.461), \mathrm{t}(101)=-2.094, \mathrm{p}=0.039$, on the item "I am proud to work for this company", concerning the Good feelings about the organization. Furthermore, there was a statistically significant difference between male $(\mathrm{M}=3.82$, $\mathrm{SD}=0.420)$ and female $(\mathrm{M}=4.00, \mathrm{SD}=0.00), \mathrm{t}(101)=-2.317$, $\mathrm{p}=0.023$, on the item "I care about the future of the company in which I work", also related to the Good feelings about the organization dimension from the Motivation factors. The results from the statistical analysis indicated that from the statements related to the Hygiene factors, there was a statistically significant difference among male $(\mathrm{M}=3.36$, $\mathrm{SD}=0.839)$ and female $(\mathrm{M}=3.67, \mathrm{SD}=0.547)$ scores in one item "My supervisor communicates well", from the Effective Supervisor dimension of the Hygiene factors $t$ (101) = $1.867, \mathrm{p}=0.065$. On the other hand, there was no significant difference between males and females on the items concerning the Relationship with Co-Workers dimension from these factors. Furthermore, an independent samples t-test was conducted to compare the level of job satisfaction of different minority status (nonminority and minority). The results showed that there was not a statistically significant difference in the scores for nonminority $(\mathrm{M}=4.00, \mathrm{SD}=1.086)$ and minority $(\mathrm{M}=4.43, \mathrm{SD}=0.787)$ on the level of satisfaction with job $\mathrm{t}(101)=-1.023, \mathrm{p}=0.309$. 
Table 5. Results of independent samples T-test analysis

\begin{tabular}{|c|c|c|c|c|c|c|c|}
\hline & Male & Female & $\begin{array}{c}\text { T-test } \\
\text { Sig.2-tailed }\end{array}$ & Non-minority & Minority & $\begin{array}{c}\text { T-test } \\
\text { Sig.2-tailed }\end{array}$ & Sig. \\
\hline $\begin{array}{l}\text { Overall, how satisfied are you with your job } \\
\text { (from1-5)? }\end{array}$ & 4.05 & 3.97 & - & 4.00 & 4.43 & - & - \\
\hline $\begin{array}{c}\text { Do you know what is expected of you at your } \\
\text { working place }\end{array}$ & 1.08 & 1.00 & - & 1.04 & 1.29 & $*$ & $* *$ \\
\hline My job is interesting and I enjoy doing it & 3.32 & 3.47 & - & 3.36 & 3.29 & - & - \\
\hline $\begin{array}{l}\text { Safety at the workplace is according to the } \\
\text { established standards }\end{array}$ & 3.53 & 3.77 & - & 3.60 & 3.57 & - & - \\
\hline My job gives me a sense of accomplishment & 3.27 & 3.23 & - & 3.27 & 3.14 & - & - \\
\hline $\begin{array}{l}\text { The company in which I work provides } \\
\text { opportunities for advancement and promotion }\end{array}$ & 2.99 & 3.37 & - & 3.10 & 3.00 & - & - \\
\hline $\begin{array}{l}\text { Information about job vacancies within the } \\
\text { company are internally available }\end{array}$ & 3.19 & 3.10 & - & 3.16 & 3.29 & - & $*$ \\
\hline I have control over how I do my work & 3.74 & 3.67 & - & 3.72 & 3.71 & - & - \\
\hline $\begin{array}{l}\text { The physical environment in which I work is } \\
\text { suitable and allows me to do my job }\end{array}$ & 3.63 & 3.87 & * & 3.71 & 3.57 & - & - \\
\hline $\begin{array}{l}\text { I have the necessary resources, tools and } \\
\text { equipment to do my job }\end{array}$ & 3.66 & 3.80 & - & 3.70 & 3.71 & - & - \\
\hline I am proud to work for this company & 3.56 & 3.83 & $*$ & 3.64 & 3.71 & - & - \\
\hline $\begin{array}{l}\text { I care about the future of the company in which I } \\
\text { work }\end{array}$ & 3.82 & 4.00 & $* *$ & 3.86 & 4.00 & $* *$ & $*$ \\
\hline $\begin{array}{l}\text { I understand how my work contributes for the } \\
\text { achievement of the company's goal }\end{array}$ & 3.75 & 3.77 & - & 3.75 & 3.86 & - & - \\
\hline $\begin{array}{l}\text { My working position is stable and I do not fear } \\
\text { that I might be fired }\end{array}$ & 3.25 & 3.53 & - & 3.31 & 3.57 & - & - \\
\hline The supervisor adequately informs its employees & 3.25 & 3.37 & - & 3.26 & 3.57 & - & - \\
\hline My supervisor communicates well & 3.36 & 3.67 & * & 3.46 & 3.29 & - & - \\
\hline Supervisors manage employees effectively & 3.34 & 3.30 & - & 3.30 & 3.71 & - & - \\
\hline Supervisors make effective decisions & 3.25 & 3.33 & - & 3.25 & 3.57 & - & - \\
\hline Supervisors care about their employees & 3.27 & 3.40 & - & 3.28 & 3.71 & - & - \\
\hline $\begin{array}{l}\text { My supervisor is approachable at any time and } \\
\text { easy to talk with }\end{array}$ & 3.53 & 3.50 & - & 3.53 & 3.43 & - & - \\
\hline My supervisor trusts me & 3.38 & 3.50 & - & 3.42 & 3.43 & - & - \\
\hline My supervisor considers my ideas & 3.22 & 3.33 & - & 3.27 & 3.00 & - & - \\
\hline $\begin{array}{l}\text { My supervisor recognizes me for doing good } \\
\text { work }\end{array}$ & 2.89 & 3.10 & - & 2.94 & 3.14 & - & - \\
\hline I trust my co-workers & 3.48 & 3.30 & - & 3.44 & 3.29 & - & - \\
\hline My co-workers respect me & 3.49 & 3.37 & - & 3.44 & 3.71 & - & - \\
\hline $\begin{array}{l}\text { I can count on my co-workers to help out when } \\
\text { needed }\end{array}$ & 3.58 & 3.43 & - & 3.55 & 3.29 & - & - \\
\hline My co-workers and I work as part of a team & 3.59 & 3.47 & - & 3.57 & 3.29 & - & - \\
\hline
\end{tabular}

$* \mathrm{p}<.05(2$-tailed), $* * \mathrm{p}<.01(2$-tailed $)$

In addition, an Analysis of variance (ANOVA) was conducted in order to explore the significance of employees' marital status with perceived work environment, job satisfaction and Motivation (Work itself, Opportunities for advancement, Responsibility, Good feelings about the organization and Clarity of mission) and Hygiene factors (Effective Supervisor and Relationship with Co-Workers).ANOVA was used to compare the variance between and within the different groups in terms of statistical significance.

Therefore, in order to explore possible difference in job satisfaction between groups' marital status, a one-way analysis of variance was performed. Accordingly, the results suggested that the marital status of the participants did not have any different impact on the level of job satisfaction $(F(4,98)=0.396, p=0.811)$. 
Table 6. ANOVA of Marital status with perceived work environment and job satisfaction

\begin{tabular}{|c|c|c|c|c|c|c|c|c|c|}
\hline & & & & & & $\begin{array}{c}\text { Between } \\
\text { Groups }\end{array}$ & $\begin{array}{l}\text { Within } \\
\text { Groups }\end{array}$ & & \\
\hline & 0 & $\begin{array}{c}\text { In a } \\
\text { relationship }\end{array}$ & Married & Divorced & $\begin{array}{c}\text { No } \\
\text { partner }\end{array}$ & $\begin{array}{l}\text { Mean } \\
\text { Square }\end{array}$ & $\begin{array}{l}\text { Mean } \\
\text { Square }\end{array}$ & F & Sig. \\
\hline $\begin{array}{l}\text { Over all, how satisfied are you } \\
\text { with your job (from1-5)? }\end{array}$ & 4.00 & 3.83 & 4.01 & 4.00 & 4.40 & .465 & 1.174 & .396 & - \\
\hline $\begin{array}{l}\text { Do you know what is expected } \\
\text { of you at your working place }\end{array}$ & 1.00 & 1.08 & 1.04 & 1.00 & 1.20 & .063 & .075 & .835 & - \\
\hline $\begin{array}{c}\text { My job is interesting and I enjoy } \\
\text { doing it }\end{array}$ & 2.50 & 3.42 & 3.34 & 3.67 & 3.50 & .505 & .487 & 1.038 & - \\
\hline $\begin{array}{l}\text { Safety at the workplace is } \\
\text { according to the established } \\
\text { standards }\end{array}$ & 3.50 & 3.25 & 3.67 & 3.67 & 3.50 & .497 & .354 & 1.403 & - \\
\hline $\begin{array}{l}\text { My job gives me a sense of } \\
\text { accomplishment }\end{array}$ & 3.00 & 3.08 & 3.25 & 4.00 & 3.40 & .589 & .628 & .937 & - \\
\hline $\begin{array}{l}\text { The company in which I work } \\
\text { provides opportunities for } \\
\text { advancement and promotion }\end{array}$ & 3.00 & 3.33 & 3.04 & 3.67 & 3.10 & .479 & .930 & .515 & - \\
\hline $\begin{array}{l}\text { Information about job vacancies } \\
\text { within the company are } \\
\text { internally available }\end{array}$ & 3.00 & 2.75 & 3.25 & 2.67 & 3.20 & .857 & .824 & 1.040 & - \\
\hline $\begin{array}{l}\text { I have control over how I do my } \\
\text { work }\end{array}$ & 4.00 & 3.50 & 3.74 & 4.00 & 3.70 & .250 & .243 & 1.026 & - \\
\hline $\begin{array}{l}\text { The physical environment in } \\
\text { which I work is suitable and } \\
\text { allows me to do my job }\end{array}$ & 4.00 & 3.33 & 3.76 & 4.00 & 3.50 & .692 & .336 & 2.060 & - \\
\hline $\begin{array}{l}\text { I have the necessary resources, } \\
\text { tools and equipment to do my } \\
\text { job }\end{array}$ & 3.50 & 3.67 & 3.75 & 4.00 & 3.30 & .538 & .362 & 1.485 & - \\
\hline $\begin{array}{l}\text { I am proud to work for this } \\
\text { company }\end{array}$ & 4.00 & 3.42 & 3.67 & 4.00 & 3.50 & .379 & .369 & 1.026 & - \\
\hline $\begin{array}{l}\text { I care about the future of the } \\
\text { company in which I work }\end{array}$ & 4.00 & 3.92 & 3.89 & 4.00 & 3.60 & .221 & .127 & 1.737 & - \\
\hline $\begin{array}{c}\text { I understand how my work } \\
\text { contributes for the achievement } \\
\text { of the company's goal }\end{array}$ & 4.00 & 3.75 & 3.75 & 4.00 & 3.70 & .083 & .251 & .331 & - \\
\hline $\begin{array}{l}\text { My working position is stable } \\
\text { and I do not fear that I might be } \\
\text { fired }\end{array}$ & 4.00 & 3.08 & 3.43 & 2.67 & 2.90 & 1.406 & .685 & 2.051 & - \\
\hline $\begin{array}{l}\text { The supervisor adequately } \\
\text { informs its employees }\end{array}$ & 3.50 & 3.17 & 3.32 & 2.33 & 3.40 & .795 & .670 & 1.187 & - \\
\hline $\begin{array}{l}\text { My supervisor communicates } \\
\text { well }\end{array}$ & 3.50 & 3.25 & 3.47 & 3.00 & 3.60 & .340 & .613 & .554 & - \\
\hline $\begin{array}{c}\text { Supervisors manage employees } \\
\text { effectively }\end{array}$ & 3.00 & 3.25 & 3.36 & 3.00 & 3.40 & .180 & .572 & .314 & - \\
\hline $\begin{array}{c}\text { Supervisors make effective } \\
\text { decisions }\end{array}$ & 3.50 & 3.08 & 3.32 & 3.00 & 3.20 & .238 & .607 & .392 & - \\
\hline $\begin{array}{c}\text { Supervisors care about their } \\
\text { employees }\end{array}$ & 3.50 & 3.00 & 3.34 & 3.67 & 3.30 & .422 & .718 & .587 & - \\
\hline $\begin{array}{l}\text { My supervisor is approachable } \\
\text { at any time and easy to talk with }\end{array}$ & 3.50 & 3.25 & 3.55 & 3.67 & 3.60 & .271 & .435 & .623 & - \\
\hline My supervisor trusts me & 3.00 & 3.25 & 3.47 & 3.00 & 3.40 & .363 & .567 & .639 & - \\
\hline $\begin{array}{c}\text { My supervisor considers my } \\
\text { ideas }\end{array}$ & 3.50 & 2.92 & 3.29 & 3.00 & 3.40 & .497 & .566 & .879 & - \\
\hline $\begin{array}{l}\text { My supervisor recognizes me for } \\
\text { doing good work }\end{array}$ & 2.00 & 2.83 & 2.99 & 3.00 & 3.00 & .526 & .925 & .569 & - \\
\hline I trust my co-workers & 3.50 & 3.33 & 3.43 & 3.67 & 3.40 & .075 & .438 & .171 & - \\
\hline My co-workers respect me & 3.50 & 3.17 & 3.50 & 3.33 & 3.50 & .305 & .412 & .741 & - \\
\hline $\begin{array}{l}\text { I can count on my co-workers to } \\
\text { help out when needed }\end{array}$ & 4.00 & 3.67 & 3.49 & 3.67 & 3.60 & .228 & .497 & .458 & - \\
\hline $\begin{array}{l}\text { My co-workers and I work as } \\
\text { part of a team }\end{array}$ & 4.00 & 3.25 & 3.57 & 3.67 & 3.70 & .442 & .609 & .726 & - \\
\hline
\end{tabular}




\section{Conclusions}

The proposed theory model for motivation was tested using data from 307 employees in a Macedonian construction company. The review of the academic literature reveals that job motivation is driven by the level of job satisfaction of employees. A range of authors' state that this is the crucial part of motivation and it is determined as the person's general attitude toward his job $(6,7)$.

The results gained on the employees overall job satisfaction with perceived work environment showed that most of the employees' were satisfied with their job $(M=4.03)$. Furthermore, the significance of Motivation and Hygiene factors was examined based on various statements related to these factors. The results gained, showed that the employees were not fully satisfied with the company's Opportunities for advancement (motivation factor), which could lead to decreased motivation and performance. On the other hand, the motivation factor that leads to employees' satisfaction was the Responsibility factor, related to the available resources, tools, and physical environment in which the employees work. Moreover, the Good feelings about the organization motivator factor lead to higher employee job satisfaction, which showed that the employees cared about the future of the company in which they worked. In addition, the Clarity of Mission (Achievement) is another motivator which, leads to rise in motivation and performance for most of the employees within this company.

On the other hand, the Hygiene factor with the highest rate to lead towards dissatisfaction is the Effectiveness of the supervisors, for supervisors not recognizing the employees when doing good work and not taking in account their ideas. The Hygiene factors with the highest possibility to lead towards decrease in job dissatisfaction are those related to the employees' Good relationship with co-workers, especially when co-workers help each other when needed and when they work as part of a team. Similar to these results, were the results gained from another study, conducted on the factors that altered dissatisfaction and satisfaction of teachers, which were in favor of and supported Herzberg's theory and disclosed that some factors, such as, achievement, recognition and responsibility were factors which most importantly lead to job satisfaction of teachers. On the other hand, poor interpersonal relations (students), interpersonal relations (peers), school policy etc., were factors which mainly resulted in teacher dissatisfaction (12). Moreover, other results which are similar to this research are those from a study conducted by Graham and Messner (13), which measured the principals' job satisfaction. The survey sample of American mid-western elementary, middle, and senior high school principals, answered to the Principals Job Satisfaction Survey (PJSS), based on Herzberg's TwoFactor Theory. The results from the analyses revealed that American mid-western principals were generally satisfied with their current job, and their level of responsibility, but, they were less satisfied with their pay, opportunities for advancement.

Furthermore, a $t$ test for independent samples was used to evaluate whether a difference existed between male and female employees. An independent samples t-test was conducted to compare the level of job satisfaction of different genders (male and female). The results showed that there was not a significant difference in the scores for male and female on the overall level of job satisfaction. But, there was a statistically significant difference between male and female employees concerning the physical environment in which they work, related to the Responsibility dimension, from the motivation factors. Female employees reported a greater level of job satisfaction with the physical environment in which they worked, than did male employees. In addition, there was also a significant difference between males and females on the item of whether they are proud to work and be part of this organization, concerning the Good feelings about the organization, motivation factor. Moreover, there was a statistically significant difference between males and females on the item concerning the future of the company, also related to the Good feelings about the organization dimension from the Motivation factors. The results from this study showed that female employees reported a greater level of job satisfaction on these items, than did male employees.

The results from the statistical analysis indicated that from the Hygiene factors, there was a statistically significant difference among males and females employees regarding Effective Supervisor. Female employees reported a greater level of job satisfaction related to the well-established communication with their supervisor, than did male employees. On the other hand, there was no significant difference between males and females on the items concerning the Relationship with Co-Workers dimension from these factors, which, showed that male and female employees were equally satisfied regarding this dimension. These findings are in line with another study that found no gender differences found male senior administrators and female senior administrators regarding work on present job, present pay, and supervision factor (14). Moreover, an independent samples t-test was conducted to compare the level of job satisfaction of different minority status (nonminority and minority). The results showed that there was no statistically significant difference in the scores for nonminority and minority on the level of satisfaction with job. This $t$ test was not significant; therefore, the null hypothesis was retained. In addition, in order to explore possible difference in job satisfaction between groups' marital status with perceived work environment and job satisfaction, a one-way analysis of variance was performed. Accordingly, from the results gained, it was concluded that the marital status of the participants did not have any different impact on the level of job satisfaction.

Regarding the influence of work environment characteristics on job satisfaction the results suggested that four Hygiene factors (satisfaction with responsibility, 
opportunities for advancement, work itself, and good feelings about organization) and four Motivational factors (effective supervision, good relationship with co-workers, work and job safety) significantly predict job satisfaction. This is in line with other studies conducted in the field. In example the findings from the Danish work environment cohort study suggested that male delivery workers have less opportunities to decide with whom they work thus resulting in more unfavourable social interaction (14).In addition the importance of opportunities for advancement and effective supervision may be that blue collar workers have lees opportunity to influence the higher levels in the organization thus reducing the opportunities for the recognition of their skills and potential (15).

This study made three fold contributions. First it expanded the existing debate on the determinants of job satisfaction among blue-collar workers. Second, the study provided a novel perspective in comparing the personal and work environment characteristics in reported job satisfaction among blue collar workers. And finally, the study provided a rare insight into the gender perspective in the construction industry. Therefore, the results of this study may help managers and human resource practitioners to increase their employee's satisfaction and productivity.

\section{REFERENCES}

[1] Schermerhorn, RJ; Hunt, GJ; Osborn, N; Uhl-Bien, M (2010) Organizational Behavior, John Wiley \& Sons, Inc, p. 110

[2] Lauby, J Sharlyn (2005) Motivating Employees p. 1 American Society for Training and Development

[3] Gitman, Land Mc Daniel, C (2007) The future of business: The Essentials, Cengage Learning, p. 308

[4] Wellington, P (2011) Effective people management: Improve
Performance Delegate More effectively handles Poor Performance and Manage Conflict. Koganpage Publishers, p. 50 .

[5] Walker, RJohn, Miller, EJack (2009) Supervision in the hospitality industry: leading human resources. John Wiley and Son, p. 177

[6] Moerdyk, A, Eckermans, G, Swanepoel, S, Schoombee, C, EkermanG (2006), X-Kit Undergraduate Human Resource Management, Pearson South Africa, p. 185

[7] Robbins, P, Sand Judge, A, T(2013) Organizational Behavior, Pearson Education, Inc., publishing as Prentice Hall, p. 207

[8] Herzberg (1966), Work and the Nature of Man. Ohio: World Publishing

[9] Wicker, D (2011) Job Satisfaction: Fact Or Fiction: Are You Satisfied with Your Job? Author House, p. 3

[10] Armstrong, M (2006) Human Resource Management Practice, $10^{\text {th }}$ Editionp. 264Kogan Page Limited

[11] Smerek, R. E. and Peterson, M (2007) Examining Herzberg's Theory: Improving Job Satisfaction among Non-Academic Employees at University, Research in Higher Education. 48(2). pp229-250

[12] Sergiovanni, T (1967) "Factors Which Affect Satisfaction and Dissatisfaction of Teachers", Journal of Educational Administration, Vol. 5Iss: 1, pp. 66-82

[13] Worley, Jewell Bevins (2006) "An Investigation of Gender Differences in Motivation of Senior Administrators in Virginia Community Colleges Using Herzberg's Two-Factor Theory." Electronic Theses and Dissertations, Paper2176.

[14] Danish Work Environment Cohort Study (DWECS) 2010. Retrieved from http: //www. arbejdsmiljoforskning. $\mathrm{dk} / \mathrm{da} /$ arbejdsmiljoedata/arbejdsmiljo-og-helbred/

[15] Hu, X., Kaplan, S., \& Dalal, R. S. (2010). An examination of blue-versus white-collar workers' conceptualizations of job satisfaction facets. Journal of Vocational Behavior, 76(2), 317-325. 